\title{
Non-Tariff Measures: What Do We Know, What Might Be Done?
}

\author{
Céline Carrère \\ CERDI and University of Geneva \\ Jaime De Melo \\ University of Geneva and FERDI
}

\begin{abstract}
With the reduction in tariff barriers, Non-tariff and behind-the-border measures (NTM and BTB) have increased in importance. This paper surveys the state of knowledge with the view to drawing implications for policy suggestions to reduce those NTM barriers that are welfare reducing. Following a description of data bases and their shortcomings, the paper reviews the state of understanding on the effects of NTMs on trade flows. The more difficult issue of translating these effects into welfare implications are covered next. The paper concludes with different approaches at reducing NTMs.
\end{abstract}

- JEL Classification: F1, F13, O24, O5

- Keywords: NTBs, NTMs, Trade Restriction.

\section{Introduction}

The evidence on the various barriers to trade--natural and policy related--points to high 'trade costs' which have been invoked to explain several puzzles in macroeconomics (see Obsfeld and Rogoff, 2000). The growing literature is also struggling to come up with better estimates of these trade costs and, for those that

\footnotetext{
*Corresponding address: Céline Carrère; CERDI and University of Geneva, celine.carrere@ unige.ch / Jaime de Melo; University of Geneva and FERDI. jaime.demelo@unige.ch. CERDI (Centre d'Etudes et de Recherches sur le Développement International) FERDI (Fondation pour les Etudes et Recherches sur le Développement International) @2011-Center for Economic Integration, Sejong Institution, Sejong University, All Rights Reserved.
} 
are policy-imposed, which ones are 'actionable', i.e. are welfare-decreasing and could be eliminated or reduced by policy action. Take two examples. The costs associated with cross-border trade between two well-integrated countries, the US and Canada, have been estimated to be as high as 70\% (see Anderson and Van Wincoop, 2004). ${ }^{1}$ Another literature on the patterns of bilateral trade is still to resolve the distance puzzle (why low-income countries do not expand trade in old and new products with partners further away in the recent decades in spite of a decline in transaction costs). ${ }^{2}$

'Trade Costs' are usually defined as the sum of administrative barriers, trade policies - tariffs and non-tariff measures (NTMs) - and transaction costs (transport and insurance costs). Sometimes the literature also refers to behind-the-border (BTB) measures to distinguish those trade costs that are not the result of trade policies. ${ }^{3}$ The conclusion of the Uruguay Round has resulted in the tarification of agriculture support measures and the elimination of the MFA, quotas, VERs and traditional other welfare-reducing NTMs (because they reduce welfare, these measures are often called NTBs) are out of the picture. As a result, attention has focused on the extensive array of NTMs and BTB measures which are part of 'trade costs'.

NTMs are often defined by what they are not (i.e. as all measures except tariffs-see Box 1). Some are covered in the WTO agreements, ${ }^{4}$ but these are measures for which disciplines are minimal (countries only have to notify changes to the WTO to increase transparency, and many countries do not notify these measures). Most efforts at reducing NTMs have either occurred unilaterally or (mostly) at the regional level and there has been little progress at harmonization at

\footnotetext{
${ }^{1}$ If these estimates seem high, they are confirmed by recent estimates of the 'border effect' based on homogenous products. Using detailed data at the Universal Product code level for 1800 stores for a large retail chain on both sides of the US-Canada border and for close to 40 million products, Gopinath et al. (2009) find that for some products a retail price discontinuity as high as $21 \%$ for stores on either side of the border while it is close to zero for stores on the same side of the border.

${ }^{2}$ See the discussion and evidence in (Berthelon and Freund, 2008, Carrère et al. (2009), Disdier and Head, 2008). Regardless of the magnitude of the 'puzzle', it is surprising that the average distance of trade for low-income countries has fallen significantly over the last thirty years.

${ }^{3}$ The terminology 'BTB measure' was first used to distinguish between 'deep' and 'shallow' integration in Regional Integration Agreements, 'deep' integration occurring when integration extends beyond the removal of protection (i.e. integrating factor markets, combining regulatory institutions, harmonizing standards and cooperating intensively on trade facilitation, e.g. reducing 'red tape' for crossing borders). ${ }^{4} \mathrm{NTM}$ provisions covered in the WTO agreements are : (i) article VII on customs valuation ; (ii) TBT agreement ; (iii) SPS agreement ; (iv) rules on import-licensing procedures ; (v) rules of origin ; (vi) PSI ; (vii) TRIMs ; (viiii) State-trading entreprises ; (ix) Trade remedies.
} 
a multilateral level.

As to BTB measures, they are not covered in WTO but, evidence suggests that they represent significant barriers to trade (all forms of transaction and administrative costs, including transport-related costs). While it is difficult to get an informed appraisal about the relative importance of NTMs vs. BTBs as barriers to trade, there is general agreement that BTBs are increasing in importance and that BTBs are the most important barrier to trade for many small landlocked or isolated economies (see Shepherd and Wilson, 2006, and Hoekman and Nicita, 2008).

From the point of view of gaining a better understanding of the importance of NTMs and of what to do about them, this paper is a survey that deals with three related questions that should help guide policies towards NTMs:

- How important are NTMs, i.e. what impact they have on trade flows? Which have been identified as most significant (across sectors, countries)?

- Which NTMs are justifiable, and for those that are not (some say NTBs, or uninformative rather than informative NTMs) what can be done?

- What approaches have been or could be used to remove NTBs.

Answering the first question helps focus on the NTMs that are binding, i.e. on those that reduce the volume of imports. This is a first step towards identifying that would be considered for policy action if they are found to be non-informative or welfare-reducing. The second, and more difficult issue, is the determination of the NTMs that are likely to be welfare-reducing. The discussion is necessarily general, reflecting the difficulty of detecting which NTMs are welfare-reducing. This leads naturally to a discussion of approaches used to remove NTBs.

This paper is complementary to our companion paper (Carrère and de Melo, 2010) which surveys methods and main results on measurement of the effects of NTMs. Section II summarizes the growing number of data bases that are coming on stream and should help developing better diagnosis. Section III reviews the different approaches used to detect the effects of NTMs on trade flows and highlights some of the main results from these studies. Section IV discusses the welfare implications of NTMs using illustrative examples. Section V reviews the alternative approaches to removing NTMs that are identified as welfare-reducing.

\section{Data on NTMs}

Until recently, the UNCTAD TRAINS-WITS data base was the only extensive data base covering NTMs for a large number of countries. It has given rise to 


Categorizing NTMs*
Cax 1
NTMs are broadly defined as any measure that causes a trade distortion but is not
a tariff whereby a distortion exists when the domestic price differs from the
border price. These include export restraints and export subsidies and the
distortions can be intentional (e.g. a QR) or a side effect of a legitimate regulatory
measure (e.g. a sanitary measure). If it is imposed explicitly to protect domestic
industry by restricting import demand, it is also known as an NTB. Distortions
mostly arise from government-imposed measures, but can also be due to
restrictive business practices. An NTB also includes internal (i.e. behind-the-
border) measure such as a production subsidy and the many juridical and
administrative measures covered under the Trade Facilitation negotiations of the
Doha Round.
Three classifications have been developed: (i) UNCTAD-TRAINS which uses the
Trade Control Measures Coding System (TCMS) broken down into six categories:
price control measures, finance measures, automatic licensing, quantity control
measures, monopolistic measures and technical measures (it excludes measures
applied to exports and production); (ii) the WTO NAMA classification based on
the 8oo measures that members must notify to the WTO under the individual
agreements---SPS, TBT, AD--- (government participation in trade, customs and
administrative procedures (rules of origin), TBTs, SPS, Specific limitations
(quotas), charges on imports (IPRs and safeguards) which is periodically
incorporated in the UNCTAD data base; (iii) the Deardorff and Stern (1997)
classification which covers much the same ground as the other two but includes
as well a broad range of macro policies (including FDI policies, national policies,
foreign exchange policies and corruption).
With the elimination of the MFA and the tarification of agricultural support
policies into two-tier tariff schemes, the number of tariff lines ridden with
quantity and price controls has fallen from 45\% in 1994 to 15\% in 20o4 while the
use of TBT has almost doubled from 32\% to 59\%, with technical regulations are
the most frequent important NTM.
* For elaboration, see World Bank (20o8), Beghin (20o6), and Hoekman and Nicita
(20o8).

several classifications (see Box 1) but it is dated and quite incomplete and is in the process of being updated. ${ }^{5}$ With the growing importance of NTMs as barriers to trade, awareness of the deficiencies of existing data bases has grown and data collection efforts are under way. ${ }^{6}$

\footnotetext{
${ }^{5}$ As explained in the annex, the data base is supposed to cover 165 countries since 1988 , but in effect only 100 countries have more or less reliable data for the period 2000-2002. The problem in the data base is that the missing entries at the HS-6 level may either refer to missing data or to no NTM on that tariff line. ${ }^{6} \mathrm{~A}$ joint UNCTAD ITC project is underway to put together a new data base that will include two components: an enhanced official component much like in the current WITS-TRAINS data base but for more measures, and also a subjective component based on detailed interviews for representative samples of exporting companies (about 400 per country). For preliminary results from a sample of 5 pilot countries, see Mimouni et al. (2009)
} 
Two main sources of information of aggregate NTMs, both for the period around 2000, are available. One is the TRAINS-WITS data base mentioned above which allows the computation of frequency and coverage ratios subject to the caveats that much of the missing information is difficult to interpret (does no entry at the HS-6 tariff line level mean no NTM or does it represent missing data?). The other is the set of World Bank Overall Trade Restrictiveness Indices (OTRI) also covering a large number of countries. These indices, discussed at greater length in our companion paper also draw on the UNCTAD data base collected around 2000 which is viewed as both deficient (are non-entries missing data or the indication of an absence of an NTM for that particular product-country pair?).

A growing number of more specific new data bases are becoming available. These include a global Anti-dumping data base, a data base on EU standards, the WTO Sanitary and Phytosanitary (SPS) Measures - Information Management System (SPS-IMS) and several data bases on trade facilitation measures. Annex 1 gives a short description of these data bases. Table A1.1 summarizes this information and gives links to access these data.

\section{Measuring the effects of NTMs on trade flows: What Does the Data tell us?}

As shown in the annotated bibliography in annex 2, until recently most assessments on NTMs has relied on computing "frequency" and "coverage" ratios, most often using the WITS-TRAINS where the NTMs are entered as binary (zeroone) variables. For well-known reasons these indicators, while a useful description of the landscape, are insufficient to serve as proxies of the effects of these NTMs since these ratios are outcome variables: a low frequency or coverage ratio could represent a very stringent NTM measure.

A more systematic analysis of the effects of NTMs has focused on evaluating their ad-valorem equivalents (AVEs), i.e. on estimating the tariffs that would result in the same reduction in imports as those attributed to the NTMs. The large majority of studies have concentrated on one of two approaches. ${ }^{7}$

The first approach uses the gravity model often focusing on the effects of NTMs on the volume of aggregate bilateral trade. For the purpose at hand, which is to

\footnotetext{
${ }^{7}$ Another approach, much less used, relies on price comparisons. It is very demanding because ideally it requires data at the product level (e.g. at the universal product code level as in Gopinath et al. (2009)). This precludes using the approach for a larger number of countries and products.
} 


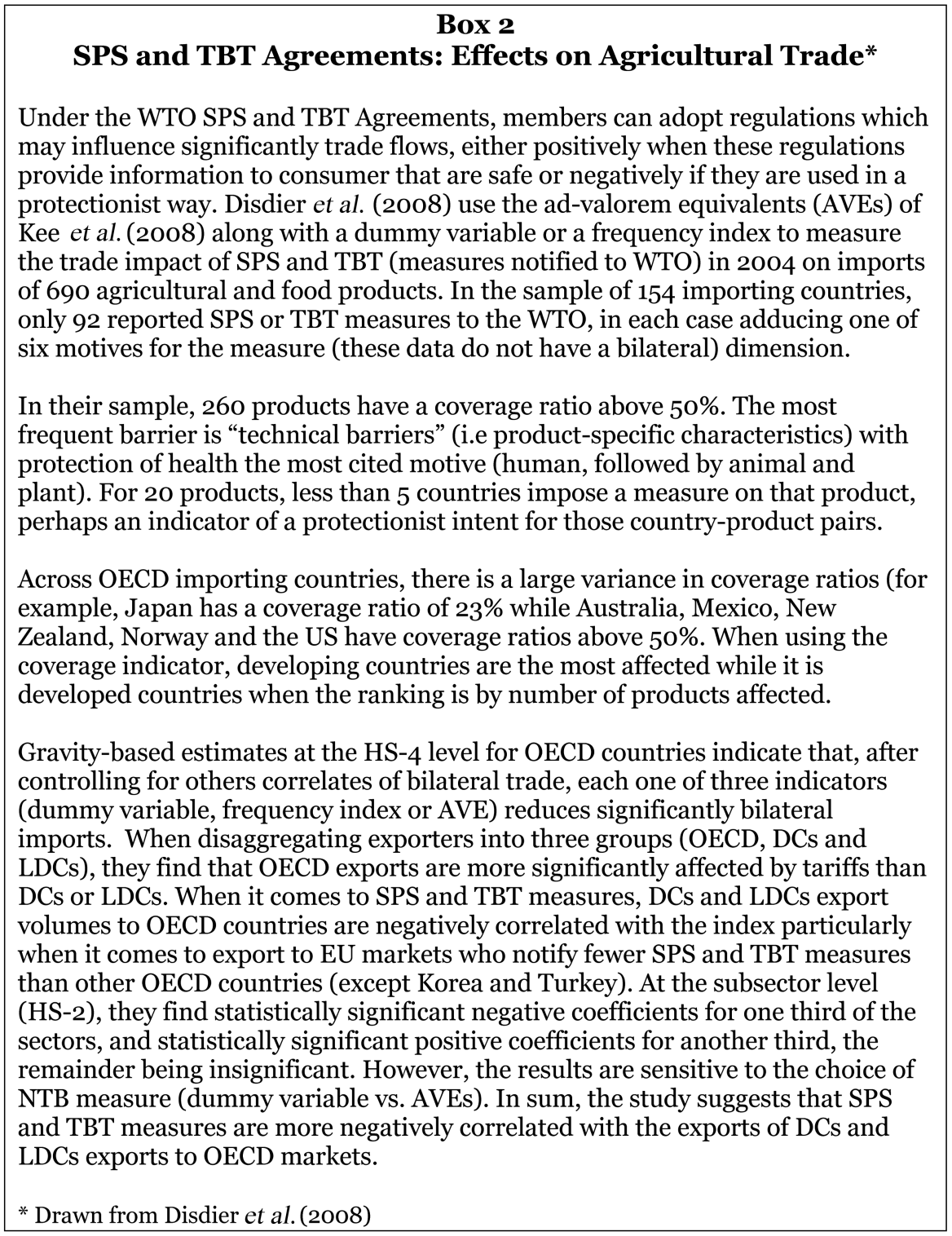

detect the effects of NTMs at the product level where they are imposed, the gravity model has several drawbacks. First, it works better for aggregate trade than for trade at the product-line level. This makes it ill-suited for the analysis of NTMs which are usually defined at the product-level. Such estimates then need to be carried out at the most disaggregated product level possible. Second, any NTM is usually imposed on imports regardless of their origin while the gravity model seeks 
to explain bilateral trade volumes making it difficult to identify the effects of NTMs on bilateral trade as shown by the lack of robustness of results to the choice of NTM indicator (see Box 2).

The second approach draws on the factor-endowment-based theories of trade focusing on the volume of trade at the product level. In that approach, the volume of aggregate trade is correlated with factor endowments, country characteristics, tariffs and various proxies of NTBs. While it has advantages for a study of the effects of NTMs at the product level, it too has drawbacks as idiosyncratic measurement errors, likely to cancel out at the aggregate level, will be magnified at the HS-6 product-line level and relevant control variables are missing. Finally, the estimate of the price elasticity of demand for imports, which is essential for computing the AVE, will likely change in magnitude with the sample period.

Both methods face a 'no-win' situation. Because the NTMs are defined at the product line level, it is desirable to avoid aggregation bias. But working at the HS-6 level is problematic because the NTMs are almost always entered as binary variables and, with $30 \%$ of tariff lines having multiple NTMs, the problem of aggregation arises. Also there is much noise in the data with biases introduced by measurement errors difficult to evaluate. Omitted-variable bias will be compounded when attempts to correct for the bias is done by using dummy variables which introduce instability in the econometric estimates because the NTMs are also captured by binary variables.

Subject to the doubtful quality of the data, the survey in our companion paper of the growing number of studies various data bases suggest: (i) NTM restrictiveness estimates based on an aggregate of 'core' NTMs are more restrictive than existing tariffs and, because of their export composition towards agricultural products, these 'core' NTMs limit market-access most for low-income countries; (ii) subject to the included controls, NTM indicators are systematically correlated negatively with bilateral trade volumes; (iii) harmonization of standards is trade enhancing; (iv) for single-NTM products (74\% of tariff lines only have one NTM measure) have an AVE of around $40 \%$ which is higher than the tariff on the corresponding line; (v) the restrictiveness of technical regulations increases with income per capita.

Case study interviews summarized in our companion paper suggest that NTMs are particularly costly for agricultural products, in part because compliance costs related to certification were usually perceived as high because the necessary infrastructure to carry them out was absent. For exporters to developing countries, arbitrariness in customs procedures and product standards are cited as a major 


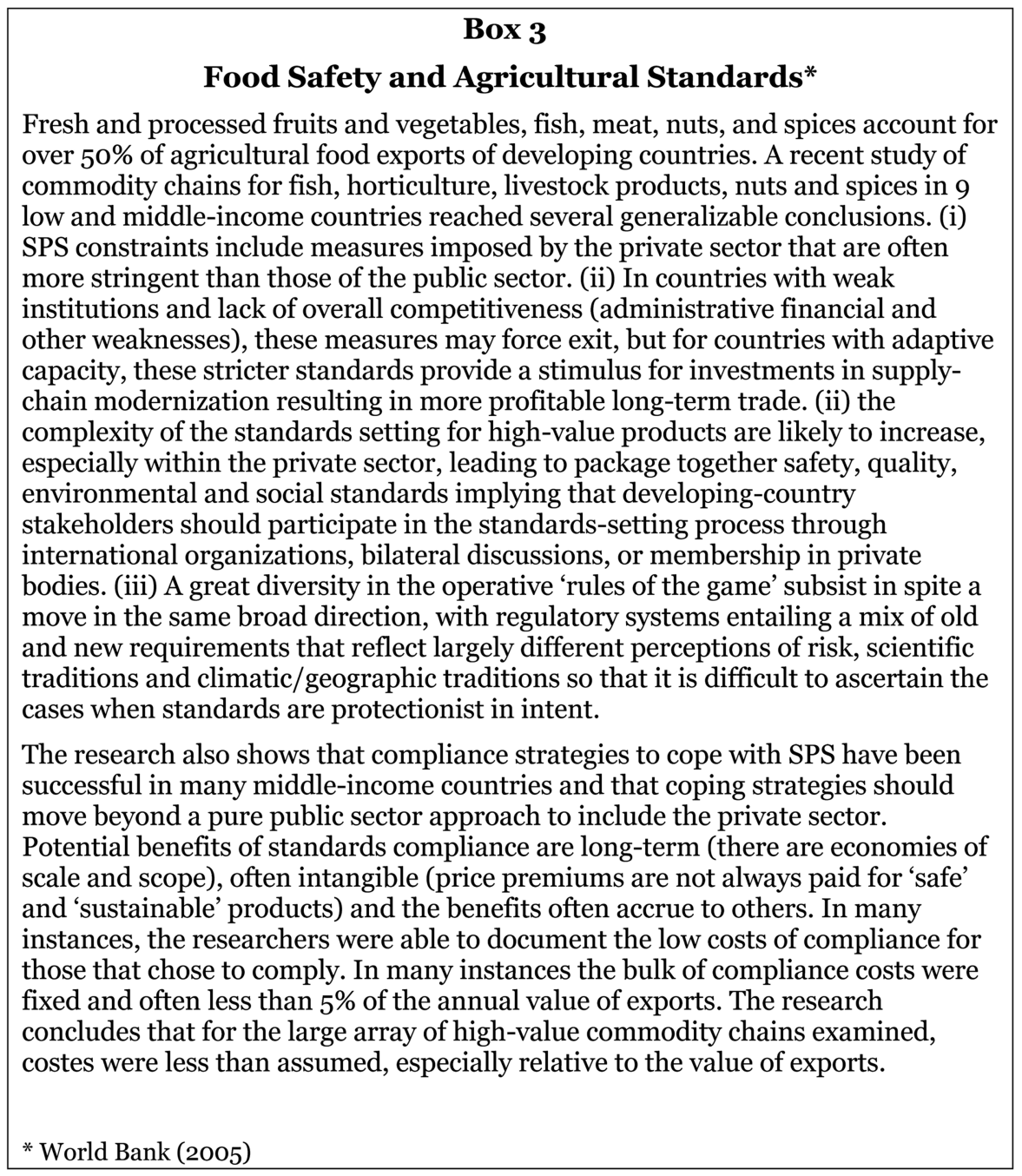

obstacle while for exporters to the EU, US and Japan, the major obstacle is the complexity and level of detail in the trade procedures with Rules of Origin often perceived as a significant barrier.

While useful, it is difficult to generalize from rankings derived from interviews conducted in these case studies. Are those interviewed representative of the universe of firms exporting in a particular sector? Interviewees are likely to refer to different products when they answer the questionnaire? Perceptions may vary according to the knowledge of the person interviewed, or according to the recent experience the person had. Perceptions are also likely to vary across countries in a given sector. Perceptions will also be different in countries with a strong social 
infrastructure (where meeting SPS and TBT standards will be easier) from those in countries with a weak social infrastructure.

To learn more about the effects of NTMs, not only case studies must complement the econometric estimates, but these studies must go beyond interviews and rely on more systematic in-depth data gathering on compliance costs. This is illustrated in the commodity-chain studies summarized in Box 3. These results confirm that there is no substitute for sector-specific expertise and that it is difficult to interpret the results from perceptions expressed in ordinal rankings in interviews.

\section{Welfare Effects of NTMs}

If measuring the effects of NTMs on trade flows is difficult, with the exception of QRs, VERs and minimum prices whose objectives are to protect domestic industries, detecting their welfare effects is even harder because the measures are complex and hence not easily quantifiable. Most importantly, the NTMs typically have several objectives, with protection a potential objective to be detected since it is hidden. Even in the case of distortionary NTBs, i.e. measures that do not address a market failure such as externalities or asymmetric information, a unified approach to measure their impact does not exist. Typically, measurement is in partial equilibrium at the product level. The analysis then attempts to separate out three effects: (i) the regulatory protection effect that provides rents to domestic producers; (ii) the supply-shift effect reflecting increased costs for foreign, and sometimes domestic, suppliers; (iii) a demand-shift effect which takes into account that the regulation may enhance demand with new information or by reducing an externality.

The three following example help illustrate the difficulties at quantification. The first illustrates the difficulty in drawing the welfare implications of SPS measures for agricultural products. The second on standards in electronic products applied by the EU, shows that harmonization of standards increases trade, and is likely to be welfare-increasing. The third, on rules of origin in PTAs illustrates that these measures are prone to capture and hence are likely to be welfare-reducing

Suppose a country imposes an SPS measure, and one uses a frequency or coverage measure to approximate the effects of the measure. First, the indicator used for the measure (usually a binary variable) does not capture the potential deterrent effect the measure may have on exporters' pricing and quantity decisions (this is not a problem with a tariff whose objective is just to reduce imports, and perhaps to 
raise revenue). Second to get the information on the relative value of the affected product, one would want to compute the coverage index on the value of imports that would have occurred in the absence of the measure, which is unobservable. Finally, when one observes the outcome resulting from the adoption of the measure, one is not sure if it is the result of a supply and/or a demand shift (the SPS measure could be informative as consumers learn about the product's characteristics perhaps via required labeling, in which case the demand curve would shift out). It is not surprising then that the results from the bilateral estimates at HS-4 level reported in Box 2 are unstable and sensitive to the choice of indicator of NTM. And even if the results were stable one would have difficulty drawing welfare implications without being informed subject to the SPS: for example, a decrease in imports of a hazardous product following the imposition of an NTM is not welfare reducing as is a reduction in imports following the imposition of a $\mathrm{QR}$, a VER or a tariff.

The effects of product standards on manufactures are also difficult to ascertain since they can have a dual impact on costs. On the one hand they may impose additional costs on exporters who may have to adopt products to the required standards in the importing country. Moreover, a producer wishing to export to several markets may be confronted to idiosyncratic standards specific to each market (in electronics, the EU imposes around 1800 standards, of which two-thirds are international common standards, see Portugal-Perez, Reyes and Wilson, 2009). To these costs, must be added certification costs. On the other hand, product standards can reduce the exporter's information costs if they convey information on industrial requirements or consumer tastes in the importing country. PortugalPerez et al. show that internationally-harmonized standards are associated with expanded EU imports of electronics while European standards not harmonized are associated with a lower effect on imports, in some cases a negative effect. Taken together, the results suggest that harmonization of standards increases welfare.

Finally, consider Rules of origin ( $\mathrm{RoO})$, necessary to prevent trade-deflection in FTAs, i.e. to prevent imports from entering the zone via the country with the lowest tariff. Even though FTAs are discriminatory in intent, RoO have the legitimate objective of preventing the unwanted extension of preferences to out-of-bloc producers which would erode the value of those preferences to eligible producers (in North-South FTAs, RoO are also sometimes justified on "developmental" grounds as they can help foster the emergence of integrated manufacturing activities in Southern partners).

RoO are notified to the WTO and figure in the NAMA-based WTO inventory of 


\begin{tabular}{|c|}
\hline $\begin{array}{c}\text { Box } 4 \\
\text { The Capture of Rules of Origin by Private Interests* }\end{array}$ \\
\hline $\begin{array}{l}\text { RoO in PTAs have two components: a small set of regime-wide and a large set of } \\
\text { product-specific rules of origin (over 500 different ones in the EU system), } \\
\text { typically defined at the HS-6 level of disaggregation. Together, both rules are } \\
\text { intended to insure sufficient transformation. The EU and the US who are the } \\
\text { main instigators of PTAs have rules that feature a large list of criteria, including } \\
\text { technical requirements such as the "triple transformation" requirement in textiles } \\
\text { and apparel, which requires apparel to be woven from originating fabric and } \\
\text { yarn. Criteria also include exceptions (making them more stringent) and } \\
\text { allowances (making them less stringent). The US relies more heavily on changes } \\
\text { of tariff classification, though often in combination with other criteria while the } \\
\text { EU relies more heavily on the value content and wholly obtained criteria. }\end{array}$ \\
\hline $\begin{array}{l}\text { To find out how stringent these rules are, researchers have constructed ordinal } \\
\text { measures of overall restrictiveness to indicate that product-specific rules with a } \\
\text { greater number of conditions to be met are more restrictive. Research based on } \\
\text { preference uptake under NAFTA and the EU system of preferences have shown } \\
\text { that after controlling for the extent of preferences, utilization rates are lower for } \\
\text { products with restrictive RoO, that restrictiveness of RoO increase with the } \\
\text { preferential margin. Detailed analysis of Mexican exports of clothing to the US at } \\
\text { the HS-8 level shows that } 1 / 3 \text { of the price rise from sales to the US under } \\
\text { preferential access goes to compensate for higher intermediate costs and the price } \\
\text { of intermediates sold by the US to Mexico rose under NAFTA. In North-South } \\
\text { PTAs, the Southern partner in effect has to buy inefficient goods from the } \\
\text { Northern partner to "pay for" preferential access. In sum, the restrictiveness of } \\
\text { RoO has been found to go beyond the levels that would be justified to prevent } \\
\text { trade deflection suggesting a capture by special interest groups. }\end{array}$ \\
\hline $\begin{array}{l}\text { Simplification of RoO accompanied by harmonization across PTAs (via the } \\
\text { multilateralization of the rules) would represent a significant step towards } \\
\text { reducing an actionable NTM. For example, LDCs could be exempted from having } \\
\text { to prove origin when preferential margins are less than } 3-5 \% \text {, and single change } \\
\text { of tariff classification, or a uniform value content rule could be adopted. In } \\
\text { addition to reducing compliance costs, such simplification cum uniformization } \\
\text { would reduce administrative costs and free customs officials (according to } \\
\text { surveys, customs officials estimate they spend close to } 1 / 3 \text { of their time on } \\
\text { checking compliance with origin requirements) for other tasks such as trade } \\
\text { facilitation. }\end{array}$ \\
\hline $\begin{array}{l}\text { Following the Hong-Kong Ministerial declaration stating that developed } \\
\text { countries should “...ensure that preferential rules of origin applicable to imports } \\
\text { from LDCs should are transparent and simple, and contributing to facilitating } \\
\text { market access (paragraph (b) in annex F of the declaration), LDCs have circulated } \\
\text { a paper (TN/CTD/"/30) suggesting a combination of value addition and local } \\
\text { content criteria. This is clearly an area in which LDCs could press harder for a } \\
\text { simplification. }\end{array}$ \\
\hline
\end{tabular}

NTMs measures as item F in Part II (Customs and Administrative Entry Procedures). Detailed inventories of RoO used by the EU and US indicate several 
hundred different RoO defined at the HS-6 level. In North-South FTAs, RoO technical requirements (e.g. the double transformation requirement in the production of clothing) coupled with the regional value content criterion have to be met to qualify for preferential access in the Northern partner's market. The Southern producers are then forced to source relatively inefficient intermediate goods locally or in Northern partners (compared to most price-competitive sources in, say, Asia).

Digging into the maze indicates that $\mathrm{RoO}$ are more restrictive for products with high preference margins. The $\mathrm{RoO}$ also end up reducing the value of preferences (compounding preference erosion in particular for Least Developed Countries). Thus, by design via the bargaining and lobbying power of the Northern firms, RoO have been captured by producers and end up as a way to "export protection" (see Box 4 for details). Clearly, RoO are an NTM whose initial intent was not protection, but which have been captured by protectionist groups and an actionable NTB (see Box 4 for measures that would reduce these costs).

\section{Approaches to Eliminating NTMs}

Given the difficulty at classifying NTMs, a practical approach is to follow the World Bank (2008a) and use the four principles required of NTMS by the WTO (i.e. transparency, non discrimination, existence of a scientific basis in the case of SPS measures and absence of better alternatives) ${ }^{8}$ This is the approach used in the classification of Table 1 which describes the main characteristics of WTO-verified NTMS. As shown in Carrère and De Melo (2009) where a tally is taken of the frequency of the main NTMs from the UNCTAD TRAINS data base, technical regulations (often in the form of SPS measures) is the most frequently used NTM (probably followed by RoO if only because of the growing number of PTAs around the world).

In Table 1, the most difficult NTMs to characterize are the technical regulations relating to sanitary measures (for the protection of human beings and animals) and the phytosanitary measures (for the protection of plant health). To be WTOcompatible, SPS measures should be harmonized to the standards guidelines and recommendations of the 'three sisters' (CODEX, IOE, IPPC) with LDCs having S\&D treatment. The difficulties involved with SPS are evident from the relatively

\footnotetext{
${ }^{8}$ This is the approach used by ASEAN in their approach at removing NTMs. Using the WTO classification also makes sense if one is looking into the future of the WTS which is more likely to be concerned with marginal adaptation of existing rules than creating or changing drastically existing rules.
} 
Table 1. A Classification of NTMs

\begin{tabular}{|c|c|c|c|c|}
\hline Type of NTM & Objective & $\begin{array}{l}\text { Potential for non transparent and } \\
\text { discriminatory application }\end{array}$ & $\begin{array}{l}\text { Scientific } \\
\text { basis }\end{array}$ & $\begin{array}{l}\text { Alternative measure that can achieve } \\
\text { objective in less distortive manner }\end{array}$ \\
\hline $\begin{array}{l}1400 \text {-Tariff quota } \\
\text { duties }\end{array}$ & Protection & $\begin{array}{l}\text { None since based on predeter- } \\
\text { mined criteria such as product } \\
\text { type and amount but discrimi- } \\
\text { nates between products }\end{array}$ & None & Tariffs \\
\hline $\begin{array}{l}2200-\text { Additional } \\
\text { charges }\end{array}$ & Revenue & $\begin{array}{l}\text { None since transparent and } \\
\text { applied uniformly on imports }\end{array}$ & None & $\begin{array}{l}\text { Uniform tax on both domestic and } \\
\text { imported products }\end{array}$ \\
\hline $\begin{array}{l}3100 \text { - Administrative } \\
\text { pricing }\end{array}$ & $\begin{array}{l}\text { Protection through price } \\
\text { control }\end{array}$ & $\begin{array}{l}\text { Non-transparent basis for price; } \\
\text { discriminates between products }\end{array}$ & None & Tariffs \\
\hline $\begin{array}{l}3400 \text { - Antidumping } \\
\text { measures }\end{array}$ & $\begin{array}{l}\text { Protection through price } \\
\text { control }\end{array}$ & $\begin{array}{l}\text { None since transparent, } \\
\text { covered by WTO Agreement }\end{array}$ & None & $\begin{array}{l}\text { Remedy already provided for under } \\
\text { WTO rules }\end{array}$ \\
\hline $\begin{array}{l}5100 \text { - Automatic } \\
\text { licensing }\end{array}$ & Monitor imports & None since freely granted & None & $\begin{array}{l}\text { Ex-post reporting of imports based } \\
\text { on customs entries }\end{array}$ \\
\hline $\begin{array}{l}6100-\text { Non- automatic } \\
\text { licensing }\end{array}$ & $\begin{array}{l}\text { Protection through quantity } \\
\text { control }\end{array}$ & $\begin{array}{l}\text { Can be nontransparent, unpredict- } \\
\text { able, arbitrary, discriminatory }\end{array}$ & None & Tariffs \\
\hline $6200-$ Quotas & $\begin{array}{l}\text { Protection through quantity } \\
\text { control }\end{array}$ & $\begin{array}{l}\text { Basis for quota may be non-trans- } \\
\text { parent; discriminates between } \\
\text { products }\end{array}$ & None & Tariffs \\
\hline
\end{tabular}


Table 1. A Classification of NTMs (continued).

\begin{tabular}{|c|c|c|c|c|}
\hline Type of NTM & Objective & $\begin{array}{l}\text { Potential for non transparent and dis- } \\
\text { criminatory application }\end{array}$ & $\begin{array}{l}\text { Scientific } \\
\text { basis }\end{array}$ & $\begin{array}{l}\text { Alternative measure that can achieve } \\
\text { objective in less distortive manner }\end{array}$ \\
\hline $6300-$ Prohibitions & $\begin{array}{l}\text { Protection through } \\
\text { quantity control; } \\
\text { also for public } \\
\text { health and safety, } \\
\text { security, environ- } \\
\text { mental, religious, } \\
\text { moral reasons }\end{array}$ & $\begin{array}{l}\text { Transparent but discriminates } \\
\text { between products }\end{array}$ & $\begin{array}{l}\text { Covers sensitive } \\
\text { products, to } \\
\text { protect health, } \\
\text { safety, morals, } \\
\text { security, } \\
\text { environment }\end{array}$ & $\begin{array}{l}\text { First establish that prohibition is not related } \\
\text { to an SPS measure; Tariffs if rationale is } \\
\text { protection; domestic tax or regulation of } \\
\text { consumption regardless of source if for } \\
\text { technical reasons }\end{array}$ \\
\hline $\begin{array}{l}6700-\text { Enterprise- } \\
\text { specific restrictions }\end{array}$ & $\begin{array}{l}\text { Selective } \\
\text { protection }\end{array}$ & $\begin{array}{l}\text { Procedures and their application } \\
\text { can be non-transparent and } \\
\text { discriminate between products }\end{array}$ & None & $\begin{array}{l}\text { Tariffs; fiscal incentives given to selected } \\
\text { sectors }\end{array}$ \\
\hline $\begin{array}{l}7100 \text { - Single channel } \\
\text { for imports }\end{array}$ & $\begin{array}{l}\text { Fiscal, economic, } \\
\text { or social }\end{array}$ & $\begin{array}{l}\text { Transparent but discriminates } \\
\text { between products }\end{array}$ & None & $\begin{array}{l}\text { Tax if fiscal; incentives if economic; tax or } \\
\text { controls on domestic consumption, or oper- } \\
\text { ation of buffer stock if social }\end{array}$ \\
\hline $\begin{array}{l}8100-\text { Technical } \\
\text { regulations }\end{array}$ & $\begin{array}{l}\text { Protect health, } \\
\text { safety, } \\
\text { environment, } \\
\text { security }\end{array}$ & $\begin{array}{l}\text { Transparent administration and } \\
\text { equal application on domestic and } \\
\text { imported products is likely; however, } \\
\text { discriminates against subjected } \\
\text { products }\end{array}$ & $\begin{array}{l}\text { Yes for health, } \\
\text { safety, } \\
\text { environment } \\
\text { or security } \\
\text { reasons }\end{array}$ & $\begin{array}{l}\text { At national level, comply with standards in } \\
\text { CODEX, IPPC and IOE; at regional level; } \\
\text { harmonization and mutual recognition of } \\
\text { standards as in the EU and to a lesser extent } \\
\text { the ASEAN }\end{array}$ \\
\hline $\begin{array}{l}8200 \text { - Pre-shipment } \\
\text { inspection }\end{array}$ & $\begin{array}{l}\text { Protect } \\
\text { government } \\
\text { revenue }\end{array}$ & $\begin{array}{l}\text { Basis for quality, quantity or price } \\
\text { evaluation can be non- transparent; } \\
\text { discriminates between products } \\
\text { and origins unless comprehensive }\end{array}$ & None & $\begin{array}{l}\text { Risk management at Customs with post- } \\
\text { entry audit }\end{array}$ \\
\hline $\begin{array}{l}\text { Customs and Adminis- } \\
\text { trative procedures } \\
\text { (Rules of Origin) }\end{array}$ & $\begin{array}{l}\text { Prevent } \\
\text { transhipment }\end{array}$ & $\begin{array}{l}\text { Usually multiple and Complex, } \\
\text { but non-discriminatory }\end{array}$ & Ambiguous & $\begin{array}{l}\text { Simplify multiple PSRO and use a uniform } \\
\text { criterion across broad category of sectors }\end{array}$ \\
\hline
\end{tabular}


large number of complaints related to the DSU. ${ }^{9}$

Next, whether NTMs are to be dealt with at the national, regional, or multilateral level, a sensible approach would be to classify them further as:

- NTMs unnecessary (such as automatic licensing)

- NTMs potentially non transparent and discriminatory (RoO)

- NTMs that are transparent but discriminatory (selected technical regulations)

- NTMs that are transparent and apply to both domestic and imported goods could be retained (unless they are welfare-reducing).

Based on this classification, elimination could then proceed in the order classified above, starting with automatic licensing and other unnecessary NTMs, then proceeding with the others.

Two approaches at eliminating NTMS have been pursued: (i) the horizontal approach which identifies priority sectors and then to eliminate NTMs plaguing these sectors; (ii) the vertical approach which would identify the NTMs measures that are most welfare-reducing. The ASEAN approach at eliminating NTMs chose the horizontal approach, identifying 11 priority sectors and classifying the NTMs into Red, Amber and Green boxes according to their restrictiveness, regulatory objectives and WTO consistency (see the discussion on the criteria for identifying priority sectors in World Bank (2008a, pp. 24-6). Either approach may be adopted but the examples in section 3 show that it is difficult to estimate the welfare effects of NTMs which is necessary whether a horizontal or vertical strategy at NTM is pursued.

Elimination of NTMs can be pursued: (i) at the national level; (ii) at the regional level in the context of an RIA in which the country participates; (iii) Multilateral, as in e.g. the Trade Facilitation negotiations at the WTO.

\section{A. National}

When pursued at the national level, there is no concern about delegation of authority to a supra-national level. Since today the vast majority of DCs and LDCs are involved in multiple reciprocal PTAs, the goal should be harmonization and recognition at the regional level so that the RIA is 'deep' and hence welfareenhancing for all members.

\footnotetext{
${ }^{9}$ As of December 2008, 35 violations to the SPS agreement had been reported with 10 panels set up to examine 11 complaints, but few developing countries have figured as either complainants or respondents in the disputes reaching the panel stage.
} 


\section{B. Regional}

To be successful, NTM removal at the regional level requires some delegation of authority to the supra-national level. The case of the EU summarized in Box 5 is the example of the deepest form of NTM removal among sovereign States.

However, other efforts have met with some degree of success. For example, APEC adopted a Trade Facilitation Plan in 1995 aiming to reduce transaction costs for businesses by $5 \%$ by 2006 . As detailed in World Bank (2008a), the ASEAN has implemented a coherent strategy for overcoming NTMs. Even if the elimination of NTMs has been moving more slowly that tariff reduction (partly due to difficult measurement issues), the ASEAN roadmap for integration specifies that NTMs are to be eliminated by 2010 for the ASEAN6, and 2018 for Cambodia, Laos, Myanmar and Vietnam. It is also noteworthy that AFTA which includes ASEAN members has adopted the simplest origin requirement to meet origin (40 regional value content or wholly obtained) for all products, which is significantly less restrictive than the more complex system of RoO adopted by virtually all other PTAs. ${ }^{10}$

Several ASEAN regional initiatives have been already eliminated some NTMs through the implementation, for instance, of the new ASEAN harmonized tariff nomenclature at the customs level in 2002, the full harmonization to international standards for some TBT dealing with consumer health and safety for 20 priory products in 2003, and for some standards with respect to electrical safety aspects in 2004. ASEAN has also followed the horizontal approach described above.

\section{Multilateral}

Little progress has been made so far under the Doha Round except for Trade Facilitation. Making trade easier or "Trade Facilitation" (TF) as it has come to be called is an integral part of reforms aimed at reducing trade costs (simplification of trade procedures, harmonization of commercial rules and transparent information and procedures as well as the recourse to new technologies allowing trade promotion and more secure means of payment). Indeed, negotiations on Trade Facilitation are the only item among the Singapore to have been included in the "July package" of 2004 and to attract relative consensus across countries. This consensus is explainable by the sharp rise in intra-industry trade, the rising

\footnotetext{
${ }^{10}$ Cadot et al. (2007) suggest that these lenient rules adopted in AFTA and

${ }^{11}$ see details on the ASEAN website and in the ASEAN program for Regional Integration Support (2005).
} 


\begin{tabular}{l} 
The Elimination of NTMs in the EU \\
\multicolumn{1}{|c|}{ Thex } \\
The single market of the EU is the most comprehensive example of economic \\
integration and elimination of NTBs based on the three principles of (i) non- \\
discrimination; (ii) mutual recognition; (iii) Community legislation to ensure the \\
functioning of the common market. The so-called four 'freedoms' that cover the \\
movement for goods, persons, services and capital is the result of the abolition of \\
customs duties, QRs, and measures having equivalent effect to customs duties \\
and QRs. Measures having equivalent effect have been defined by the European \\
Court of Justice as “All trading rules enacted by Member States which are capable \\
of hindering, directly or indirectly, actually or potentially, intra-Community trade \\
are considered as having an effect equivalent to QRs." Some sixteen measures \\
have been identified as having equivalent effects. The EC also prohibits all types \\
of trade remedies which include Anti-dumping, safeguards and countervailing \\
measures. In addition, under Mutual Recognition, a Member State may not \\
prohibit the sale of goods lawfully produced in another Member State (the 1979 \\
Cassis de Dijon Case). New law (harmonized legislation) was adopted when \\
existing rules (mostly on health, safety or environmental protection) differed too \\
much across Members and starting in 1985 physical barriers (border checks and \\
customs formalities) were eliminated. \\
In spite of substantial supra-national delegation of authority to the European \\
Commission, progress in some areas having equivalent effects like public sector \\
purchases of non-domestic origin were slow, so the Single Action Plan was \\
adopted in 1997 to speed up the necessary integration of the Single Market with a \\
scoreboard of implementation put in place. The Action Plan also dealt with \\
formal infringement procedures. If the country fails to comply after the \\
procedure, the European Court of Justice has the power to impose penalty \\
payments and take away privileges under the trader from the country as a last \\
resort.
\end{tabular}

exchange of intermediate goods, and the verticalization of production in the supply chains that has accompanied the delocalization of activities from developed to developing The TF negotiations which are to deal with articles V ('transit freedom' which is extremely important for LDCs, 16 of the 50 being landlocked), VIII ('fees and formalities Related to the Import and export', i.e. red-tape) and X ('publication and application of rules related to international trade'). A second reason for the consensus in carrying out TF negotiations is that the elimination of the red-tape creates relatively few rents and these measures are not easily subject to capture by officials. In spite of significant fixed costs for LDCs (which could be borne by technical assistance), it is expected that significant market access and increased competitiveness will be achieved by the TF negotiations.

\section{Conclusions}

Estimates of trade costs are high so the issue is to detect where these trade costs 
come from. The literature has shown that trade flows are sensitive to both NTMs and BTB measures, some estimates suggesting that BTB measures are higher than NTM measures. Much progress is forthcoming on selected BTB measure via initiatives on Trade Facilitation at the multilateral level. This paper concentrates on NTMs: detecting their effects, and finding out if the reduction in trade flows is welfare reducing.

With the elimination of $t$ bulk of QRs, VERs and other 'traditional' welfarereducing NTMs, the remaining NTMS are technical barriers to trade. Examples in the paper show that it is difficult to detect when these regulations are 'actionable', i.e. welfare reducing because their intent is not easy to detect. This is particularly the case for SPS measures for which is it difficult to ascertain if they have protectionist intent. In the case of Rules of Origin which have the legitimate objective of preventing trade deflection, in practice, they have been captured by protectionist interest groups and are more clearly actionable.

Proceeding forward requires first a classification of NTMs as to their Usefulness, regardless of intent (for example automatic licensing can be removed), then figuring out if they are discriminatory against imports or have a welfare cost in which case they should be removed. The sequencing of removal has varied across countries and depends on the context. Some NTMs can be removed unilaterally but, given that most countries are engaged in RIAs, a regional approach would be preferable since it brings into focus the gains from harmonization across countries. Multilateral approaches are also desirable but more difficult to achieve because countries are hesitant to give up the necessary sovereignty to move forward.

Received 19 January 2011, Revised 21 February 2011, Accepted 22 February 2011

\section{References}

Anderson, J., J. Bergstrand, P. Egger, and J. Francois (2008), Non-Tariff Barrier Study Methodology, mimeo ECORYS.

Anderson, J. and E. Van Wincoop (2004), Trade Costs, Journal of Economic Literature, 42(3), 691-751.

Andriamananjara S., Dean J.M., Feinberg R., Ferrantino M.J., R. Ludema and M. Tsigas (2004), The effects of Non-Tariff Measures on Prices, Trade and Welfare: CGE Implementation of Policy-Based Price Comparisons, US international trade commission WP \#2004-04-A. 
APEC Secretariat (2005), Quantitative Methods for Assessing the Effects of NTM and Trade Facilitation, World Scientific.

Becker G. (2005), Non-Tariff Measures -Issues for Sub-Saharan Africa, UNDP report.

Beghin J.C. and J.C. Bureau (2001), Quantification of Sanitary, Phytosanitary and Technical Barriers to trade for Trade Policy Analysis, Center for Agricultural and Rural Development, Working Paper WP291.

Beghin J.C. (2006), Nontariff Barriers, forthcoming in the New Palgrave Dictionary of Economics.

Berthelon, M., and C. Freund (2008), On the Conservation of Distance in International Trade, Journal of International Economics, 75, 310-20.

Bora B., Kuwahara A. and S. Laird (2002), Quantification of non-tariff measures, UNCTAD Policy issues series \#18.

Cadot, O. , A. Estevadeordal, A. Suwa-Eisenmann and T. Verdier eds. (2006), The Origin of Goods: Rules of Origin in Regional Trade Agreements, Oxford.

Cadot, O. and J. de Melo (2008), Why the OECD Should Reform their Rules of Origin, World Bank Research Observer.

Cadot, O., J. de Melo and A. Portugal-Perez (2007), Rules of Origin for Preferential Trading Arrangements: Implications for AFTA of EU and US Regimes, Journal of Economic Integration.

Carrère, C., J. de Melo and J. Wilson (2009), The Distance Effect and the Regionalization of Trade of Low Income Countries, mimeo WB.

Carrère, C., J. de Melo (2011), Notes on Detecting the Effects of Non-Tariff Measures, Journal of Economic Integration, 26(1), 135-167.

Deardorff A.V. and R. Stern (1997), Measurement of Non-Tariff Barriers, OECD Working Papers \#179.

Disdier A.C. and Head, K. (2008), The Puzzling Persistence of the Distance Effect on Bilateral Trade, The Review of Economics and Statistics.

Disdier A.C., L. Fontagné, and M. Mimouni (2008), The Impact of Regulations on Agricultural Trade: Evidence from the SPS and TBT Agreements, American Journal of Agricultural Economics, 90(2), 336-50.

Donelly W.A. and D. Manifold (2005), A compilation of Reported Non-Tariff Measures: Description of the information, US international trade commission Working Paper \#2005-05-A.

Gopinath, G., P-O. Gourinchas, C-T Hsieh, N. Li (2009), Estimating the Border Effect: Some New Evidence, NBER Working Paper No. w14938.

Hoekman, B. and A. Nicita (2008), Trade policy, trade costs, and developing country trade, World Bank Policy Research WP \#4797.

Kee, H., A. Nicita and M. Olarreaga (2008), Import Demand Elasticities and Trade Distortions, The Review of Economics and Statistics.

Kee, H., A. Nicita and M. Olarreaga (2009), Estimating Trade Restrictiveness Indices, Economic Journal, 119, 172-99.

Linkins L.A. and H.M. Arce (1994 revised in 2002), Estimating Tariff-Equivalents on 
Non-Tariff Barriers, US international trade commission Working Paper \#1994-06$\mathrm{A}(\mathrm{r})$.

Mimouni, H., C. Averbeck, and O. Skorobogatova (2009), Obstacles to Trade from the Perspective of the Business Sector: A Cross-country Comparison, chapter 1.6 in The Global Enabling Trade Report, WEF, Geneva.

Obsfeld, M. and K. Rogoff (2000), The Six Major Puzzles in Macroeconomics: Is there a Common Cause?, NBER Macroeconomics Annual.

Portugal Perez A., Reyes and J. Wilson (2009), Beyond the information technology agreement: harmonization of standards and trade in electronics, Policy Research Working Paper \# 4916.

Shepherd, John, and J. Wilson (2006), Road Infrastructure Network in Europe and Central Asia: Does Network Quality Affect Trade?, Policy Research Working Paper \#4101. World Bank (2005), Food Safety and Agricultural Standards: Challenges and Opportunities for Developing Country Exports, Report 31207.

World Bank (2008a), A Survey of Non-Tariff Measures in the East Asia and Pacific Region, Policy Research Report.

World Bank (2008b), Non-Tariff Measures on Goods Trade in the EAC, Report \#45706AFR.

\section{Appendix}

\section{Annex1. Data Bases on NTMs and Trade Facilitation}

This annex describes the main data bases on NTMS and trade facilitation available. Table A1.1 describes the agency responsible for each data base, what is in the data base, the URL to access the data base (when it exists) and the e-mail address for inquiries. ${ }^{12}$ Follow some comments on these databases.

We describe first two data bases dealing with estimates of the combination of all NTMs. This is followed by a brief description of the main NTM-specific databases. ${ }^{13}$

UNCTAD TRAINS - WITS. The main international datasets on NTMs can be found in the UNCTAD TRAINS data base (through the WITS software). The WITS includes frequency data (i.e. it indicates whether a country has a particular NTM at the Harmonized System 6-digit (HS-6) classification level. These NTMs

\footnotetext{
${ }^{12}$ This table is taken from the more exhaustive description distributed at a recent two-day meeting "Data Day at the WTO" available at http://www.wto.org/english/res_e/statis_e/data_day_may09_e/ brochure_dataday_may09_e.pdf

${ }^{13}$ See the survey in Annex 1 table A1.1. Some of the databases described in this subsection are discussed in more details in a very informative note titled "trade and market access data for policy makers" and available at: http://www.wto.org/english/res_e/statis_e/data_day_may09_e/brochure_dataday_may09_e.pdf
} 
Table A1.1. Summary table listing the databases on NTMs and Trade Facilitation

\begin{tabular}{|c|c|c|c|c|}
\hline Organization & Title & Section & URL & Contact \\
\hline ITC & $\begin{array}{l}\text { Market Access Map } \\
\text { (MacMap) }\end{array}$ & Tariffs and trade & www.macmap.org & $\begin{array}{l}\text { marketanaly- } \\
\text { sis@intracen.org }\end{array}$ \\
\hline $\begin{array}{l}\text { World Bank } \\
\text { UNCTAD }\end{array}$ & $\begin{array}{l}\text { World Integrated Trade Solution } \\
\text { (WITS) }\end{array}$ & Tariffs and trade & http://wits.worldbank.org/witsweb & wits@worldbank.org \\
\hline WTO & $\begin{array}{l}\text { Sanitary and Phytosanitary } \\
\text { Measures - Information Man- } \\
\text { agement System (SPS-IMS) }\end{array}$ & $\begin{array}{l}\text { Non-tariff mea- } \\
\text { sures, Agriculture } \\
\text { specific issues }\end{array}$ & http://spsims.wto.org/ & spsims@wto.org \\
\hline World Bank & $\begin{array}{l}\text { Overall Trade Restrictiveness } \\
\text { Indices }\end{array}$ & Non-tariff measures & $\begin{array}{l}\text { http://econ.worldbank.org/WBSITE/EXTER- } \\
\text { NAL/EXTDEC/EXTRESEARCH/0,,content- } \\
\text { MDK:21085342 pagePK:64214825 piPK:64 } \\
\text { 214943 theSitePK:469382,00.htm }\end{array}$ & World Bank \\
\hline World Bank & $\begin{array}{l}\text { Logistics Performance } \\
\text { Indicators }\end{array}$ & Trade facilitation & http://www.worldbank.org/lpi & $\begin{array}{l}\text { tradefacilita- } \\
\text { tion@worldbank.org }\end{array}$ \\
\hline World Bank & World Trade Indicators & Trade facilitation & $\begin{array}{l}\text { http://web.worldbank.org/WBSITE/EXTER- } \\
\text { NAL/TOPICS/TRADE/0,,content- } \\
\text { MDK:21393040 pagePK:210058 piPK:2100 } \\
\text { 62 theSitePK:239071,00.html }\end{array}$ & $\begin{array}{l}\text { ryatawara@world- } \\
\text { bank.org }\end{array}$ \\
\hline $\begin{array}{l}\text { World Economic } \\
\text { Forum }\end{array}$ & $\begin{array}{l}\text { Global Enabling Trade } \\
\text { Report }\end{array}$ & Trade facilitation & $\begin{array}{l}\text { http://www.weforum.org/en/initiatives/gcp/ } \\
\text { GlobalEnablingTradeReport/index.htm }\end{array}$ & $\begin{array}{l}\text { World Economic } \\
\text { Forum }\end{array}$ \\
\hline
\end{tabular}


(often referred to as "core" NTMs are described in Table A1.2. This classification corresponds to UNCTAD's Coding System of Trade Control Measures). Exact information included in WITS is reported in Table A1.3. It is this data base that has been used to compute "frequency ratios" or "trade coverage ratios" of NTMs across countries and products (see for instance Bora, Kuwahara and Laird, 2002).

WITS covers theoretically 165 countries (counting European Union as one country) with time span from 1988 to present. However, there are a lot of missing values. In fact, NTM data are actually available for around 100 countries, and not always for recent years. A further difficulty is interpreting the cells with a zero since it may not necessarily reflect the absence of an NTM for the corresponding country/product, but rather missing data. When using WITS data, if possible, one should complement this with data from other sources (as in e.g. Kee et al., 2009, who complete WITS data with information provided by the WTO's trade policy review and by the EU standard's database).

World Bank Overall Trade Restrictiveness Indices. This data base contains several indices computed by Kee et al. (2009). It includes an Overall Trade restrictiveness Index (ORTI) (an aggregate of tariff and non-tariff measures). ${ }^{14}$ The data base also includes an estimate of the ad-valorem equivalent (AVE) of "core" NTBs at the country/HS6 product categories level.

Global Antidumping Database. This database hosts recently collected publicly and freely available detailed data on twenty-five (as of the completion of version 5.0) different national governments' use of the antidumping (AD) trade policy instrument, as well as all WTO members' use of safeguard (SG) measures, Chinaspecific transitional safeguard (CSG) measures, and most of the global users of countervailing duties (CVD) through 2008.

WTO Sanitary and Phytosanitary Measures - Information Management System (SPS-IMS). The SPS-IMS provides access to WTO-related information on food safety and animal and plant health (sanitary and phytosanitary or SPS measures).${ }^{15}$ The system allows users to track and obtain information on SPS measures that Member governments have notified to the WTO, on specific trade concerns raised in the SPS Committee, on documents of the WTO's Sanitary and Phytosanitary Measures Committee, and on Member governments' enquiry points and notification authorities.

\footnotetext{
${ }^{14}$ freely available at http://econ.worldbank.org/WBSITE/EXTERNAL/EXTDEC/EXTRESEARCH/0, contentMDK:21085342 pagePK:64214825 piPK:64214943 theSitePK:469382,00.html

${ }^{15}$ available at http://spsims.wto.org/

${ }^{16}$ available at http://go.worldbank.org/6OEYNCYSD0
} 
EU Standards database The EU Standards Database ${ }^{16}$ collates European standards for agricultural products and textiles/clothing over the period 1995-2003, and maps them to the Harmonized System. For each product-year combination, counts are given both of the number of standards and of the number of pages of standards. In general, rapid growth is observed both in the number and average length of standards.

Survey on EU-US NTBs Within the context of the "Study on Non-Tariff Measures to EU-USA Trade and Investment" financed by the European Commission (and ending in 2010), the ECORYS' team (see details at http://ntb.ecorys.com/) will identify the main NTMs (the final report is still forthcoming), based on "a worldwide business survey". ${ }^{17}$ The business survey is used also to estimate the height of the NTMs (i.e. construct NTM indexes at country-pair level). For this reason, the survey is worldwide instead of just EU-US specific. They estimate the height of the NTMs compared to other countries that export to the EU and/or US. Similarly, the business survey collects detailed information on the main barriers to trade, investment and foreign affiliate sales for each sector.

\subsection{NTMs in WITS (World Integrated Trade Solution)}

The UNCTAD Trains database contains information on non-tariff measures following the categories summarized in Table A1.2 (see the detailed UNCTAD Coding System of Trade Control Measures online http://r0.unctad.org/trains_new/ tcm.shtm). The UNCTAD-TRAINS website also reports information on which countries have submitted information on NTM (and the latest year for which such

Table A1.2. Non-Tariff Measures in TRAINS

\begin{tabular}{lll}
\hline Code & Measure & Example \\
\hline 3 & Price Control & minimum import price \\
4 & Finance & Advance payment of customs duties \\
5 & Licensing & Prior surveillance \\
6 & Quantity controls & Seasonal quotas \\
7 & Monopolistic & Sole importing agency \\
8 & Technical & Packaging requirement \\
\hline
\end{tabular}

Source: WITS summary TDW catalog (2009)

\footnotetext{
${ }^{17}$ The online business survey was closed by the end of July 2008 with 5.500 responses received. See http:/ /ntm.ecorys.com/index.php?option=com_content\&task=view\&id=40\&Itemid=94. Results not publicly available.
} 
data are available (cf. http://r0.unctad.org/trains_new/datacoverage.shtm)

\section{Annex 2. Annotated Bibliography of recent Papers dealing with the Measure- ment of NTMs}

1. Anderson, J. and E. Van Wincoop (2004), Trade Costs, Journal of Economic Literature, 42(3), 691-751.

Subject: Most thorough critical review of the literature on the size of international trade barriers with emphasis on methodological issues and on estimates of the 'border effect'. Heavy emphasis on the benefits and costs of using the gravity model to assess trade costs.

2. APEC Secretariat (2005), Quantitative Methods for Assessing the Effects of NTM and Trade Facilitation, World Scientific.

Subject: Introduction with collection of essays on NTMs (including in services). Most comprehensive review of different approaches at quantification. Includes several papers listed here (e.g. . Bora, Kuwahara and Laird, 2002, and Deardorff and Stern, 1997) and a short introduction to WITS.

3. Andriamananjara S., Dean J.M., Feinberg R., Ferrantino M.J., R. Ludema and M. Tsigas (2004), The effects of Non-Tariff Measures on Prices, Trade and Welfare: CGE Implementation of Policy-Based Price Comparisons, US international trade commission Working Paper \#2004-04-A (29 pages).

Subject: Estimates the percentage increase in specific product prices across countries due to NTMs. Uses GTAP simulations. Assesses the trade impact of different type of trade.

Sample: 14 products and 18 countries/regional groups, year 2001.

Data: 2 dummies for NTMs computed from UNCTAD trains data and USITC NTM database, prices data from the EIUS CityData.

4. Becker G. (2005), Non-Tariff Measures -Issues for Sub-Saharan Africa, UNDP report (105 pages).

Subject: A standard discussion of NTMs. Notes that certain NTMs are more important than others for SSA countries (provides a checklist of 43 priorities to consider!). Paper argues that regional integration in SSA could be a way to address NTMs (and also the EPA negotiations). No evidence to support the arguments in the paper.

5. Beghin J.C. and J.C. Bureau (2001), Quantification of Sanitary, Phytosanitary and Technical Barriers to trade for Trade Policy Analysis, Center for Agricultural and Rural Development Working Paper WP291 (35 pages). 
Subject: exhaustive survey of literature that models and quantifies NTBs to trade in the agricultural and food sectors (price-wedge method, inventory-based approaches, survey-based approaches, gravity-based approaches, risk-assessmentbased cost-benefit measures, stylized microeconomic approaches, quantification using sectoral or multi-market models)

6. B. Bora, A. Kuwahara and S. Laird (2002), Quantification of non-tariff measures, UNCTAD Policy issues series \#18 (42 pages).

Subject: Comprehensive review of various approaches to measure and quantify NTMs within the context of existing data sets. It covers much of the same ground as Deardorff and Stern (1997). Has a clear presentation of the pros and cons of different approaches.

The paper applies the same methods as in other reports (i.e. inventory approach, tariff equivalent, TRI, etc.). The only tables reported are NTB coverage for selected countries and some frequency statistics of NTBs. The paper comes up with the same conclusion: "the existing collection on NTBs, while better than nothing, needs to be improved".

Part II, gives good and exhaustive description of available data on NTMs in WITS (products and countries coverage). Analysis is only in terms of frequency (the only analysis possible from WITS database).

Sample: countries available in WITS, latest available year.

Data:from WITS.

7. A.V. Deardorff and R. Stern (1997), Measurement of Non-Tariff Barriers, OECD Working Papers \#179 (117 pages).

Subject: Thorough analytical framework that shows that one cannot satisfactorily isolate the effects of an NTB since the outcome of an NTB reflects the measure itself and any other changes, e.g. supply response. Assesses the different methods for quantifying NTBs. Subsequent papers are often very similar in methodology and classification to this paper.

Classification of NTBs (The 5 broad categories of UNCTAD) : (i) quantitative restrictions and similar specific limitations; (ii) non-tariff charges and related policies affecting imports; (iii) government participation in trade, restrictive practices and more general government policies; (iv) customs procedures and administrative practices and (v) technical barriers to trade (see their appendix 1).

Reviews different measurement methods (with some descriptive statistics):

The presence or size of NTBs (Frequency-type measures, price-comparison measures, quantity-impact measures as well as some NTB-specific methods) 
The Effects of NTBs (effective rates of protection, effective rate of assistance, trade restrictiveness index, applied general equilibrium model measures).

Sample: Case studies in the OECD pilot group. Selected countries for the OECD Pilot Group: Australia, Canada, Germany, Norway, United Kingdom/EU, US.

Data: from UNCTAD database and diverse case studies on NTBs done in 1995

8. W.A. Donelly and D. Manifold (2005), A compilation of Reported Non-Tariff Measures: Description of the information, US international trade commission Working Paper \#2005-05-A (18 pages).

Table 2. NTM categories used in this compilation

\begin{tabular}{ll}
\hline anticompetitive practices / competiton policy & intellectual propety rights \\
corruption & investment-related measures \\
customs procedures & sanitary adn phytosanitary measures \\
export-related measures & services \\
govemment procurement & standards, testing, certification and labeling \\
import licensing & state-trading \\
import prohibitions & taxes \\
import quotas & \\
\hline
\end{tabular}

Subject: This compilation provides information on the following 15 NTMs for goods and services

Sample: 53 countries (Table 1) with a focus on members of the APEC and FTAA.

Data: 3 sources of information:

i) the Office of the United States Trade Representative's (USTR) National Trade Estimate Report on Foreign Trade Barriers (NTE) $;^{18}$

ii) the European Union's (EU) Market Access Database, ${ }^{19}$

iii) the World Trade Organization's (WTO) Trade Policy Reviews. ${ }^{20}$

Framework: Quantitative description from their matrix of data: number of each type of NTM per countries, or of each type of generic barriers by each category of NTM, number of NTM by sector and product, etc.

9. B. Hoekman and A. Nicita (2008), Trade policy, trade costs, and developing country trade, World Bank Policy Research WP \#4797 (29 pages).

Subject: Thorough and most comprehensive aggregate measure of aggregate

\footnotetext{
${ }^{18} \mathrm{http} / / /$ www.ustr.gov/Document_Library/Reports_Publications/2002/2002_NTE_Report/Section_ Index.html

${ }^{19} \mathrm{http}: / / \mathrm{mkaccdb}$.eu.int/mkaccdb2/indexPubli.htm

${ }^{20} \mathrm{http}: / /$ www.wto.org/english/tratop_e/tpr_e/tpr_e.htm
} 
effects of NTMs on the volume of bilateral trade. Uses a gravity equation to assess the trade impact of different type of trade restrictions applied at the border. Use of several indexes of trade restriction ,i.e. the TRI of Kee, Nicita and Olarreaga (2008) and the overall trade restrictiveness index (OTRI) used by the WB and the IMF (2008), the latter including both the effect of tariffs and NTMs. It is clearly superior to the more commonly used indicators such as NTM frequency and coverage ratios since it takes into account the elasticity of import demand with respect to prices.

In addition to the OTRI (that captures only a subset of the policies that result in impediments to trade), NTMs are proxied by (i) Logistic performance index LP from the WB (ii) the trade facilitation index from the IMD's World Competitiveness yearbook 2000 and others (iii) the "Doing Business" cost of trading from Djankov, Freund and Cong 2006.

All these indicators are included in a cross section gravity equation estimated using the PPML estimator.

Sample: 104 importers and 115 exporters, year 2006.

Data: See above

10. L.A. Linkins and H.M. Arce (1994 revised in 2002), Estimating TariffEquivalents on Non-Tariff Barriers, US international trade commission Working Paper \#1994-06-A(r) (23 pages).

Subject: Reviews the measurement of NTBs with a specific focus on commonly used methods for measuring tariff equivalents (Frequency measures, restrictiveness of quantitative restraints, estimation of tariff or export tax equivalents, etc.). Provide a comparison of the Canadian and US applications. Same approach and classification as in 2.

Classification of NTBs $=$ still the 5 broad categories of UNCTAD.

Sample: Canada and US.

Data: from Canada's department of finance (1988) and US international trade commission (1991).

11. World Bank (2008a), A Survey of Non-Tariff Measures in the East Asia and Pacific Region, Policy Research Report.

Subject: Up-to-date review of the literature on NTM measurement along the lines in Bora et al. (2002) and Deardorff and Stern (1997) recognizing that their effects cannot be measured satisfactorily, nor can they be ranked, justifying a case study approach. Good discussion of the avenues to reduce NTMs at the multilateral (WTO) and at the regional levels and of the experience of the EU, NAFTA, and 


\section{ASEAN.}

Sample: 10 Country Studies bases on survey of exporters. Concludes that compliance costs vary across three dimensions: (i) exporters for given NTMs; (ii) across product categories i.e. agriculture vs. manufactures; (iii) and across destinations i.e. the EU and US vs. a developing country like China. 